\title{
Wear Test of Composite Restorative Materials by a Polishing Machine
}

\author{
Naoki SATOU, Aki YUUKI, Junko SATOU, Makiko KAI, Hideaki SHINTANI and \\ Tokio INOUE \\ Department of Operative Dentistry, Hiroshima University School of Dentistry, 1-2-3 Kasumi, Minamiku, \\ Hiroshima 734, Japan
}

Received on March 31, 1986

The wear resistance of microfilled and conventional composite resins, was examined, using two sizes of abrasive particles for polishing. The mechanical properties of the composite resins were also studied and evaluated in relation to wear. Conventional composites showed much lower wear resistance than the microfilled resins. The amalgam and human enamel abraded with $10 \mu \mathrm{m} \mathrm{SiC} \mathrm{particles,} \mathrm{had} \mathrm{strongest} \mathrm{wear}$ resistance, and those abraded with $20 \mu \mathrm{m} \mathrm{SiC} \mathrm{particles} \mathrm{had} \mathrm{resistance} \mathrm{similar} \mathrm{to} \mathrm{that} \mathrm{of} \mathrm{the} \mathrm{microfilled} \mathrm{resins}$ in wear. The effect of the size of the abrasive particles on wear differed with the material tested. Filler content, the mechanical properties of knoop hardness, elastic modulus and destructive energy correlated well with wear rate.

Key words: Wear test, Composite resin, Abrasion

\section{INTRODUCTION}

Application of composite resin is expected to spread to the posterior teeth as well as to the anterior teeth. For both anterior and posterior restorations, adequate wear resistance is an important requirement. Clinical wear patterns have often been estimated by observing replicas under a scanning electron microscope, and it is the most reliable method for abrasion studies. However, clinical trials are time-consuming and only a limited number of material can be examined at the same conditions. Therefore, the development of a reliable in vitro wear test for the wear under masticatory function is desired. Wear resistance has been studied in vitro ${ }^{1,2)}$, though the results have often been in disagreement with the clinical findings $\mathrm{s}^{3-5)}$ and in vitro wear test seems to be influenced by the choice of test parameters. The abrasive wear resistance of seven composite resins, an amalgam and tooth enamel was examined using a polishing machine (VIBRO-POLISH) developed for preparing a microscopic sample with sliding and vibrating. Two abrasive particle sizes of slurries were used.

\section{MATERIALS AND METHODS}

Specimen preparation: Seven conventional composite resins were studied along with an amalgam, spherical D and human enamel (Table 1). The specimens were mixed according to the manufacturers' directions. Specimens for testing were produced in a separating stainless steel mould ( $\phi 8 \mathrm{~mm} \times 4 \mathrm{~mm}$ height). The resins were polymerized against a polyester matrix strips for $30 \mathrm{~min}$. The amalgam was mixed and placed with a slight excess in the described mould. Condensation was accomplished mechanically with an Amalpac instrument (Midwest Dental Mfg. Co., Melrose Park, Ill). The excess amalgam was removed, and the surface was smoothed with a slide glass. After $30 \mathrm{~min}$, the specimen was stored in $37^{\circ} \mathrm{C}$ water 
Table 1 Materials used

\begin{tabular}{lcc}
\hline \multicolumn{1}{c}{ Materials } & Manufacturer & Batch No. \\
\hline P-10 & 3M & $2885-2$ \\
Clearfil Posterior & Kuraray & 11113 \\
Clearfil F II & Kuraray & 11132 \\
Adaptic & J\&J & $1 \mathrm{~A} 001$ \\
Silar & 3M & 8601 \\
Microrest AP & GC & 031041 \\
Superlux & DMG & 31241 \\
Spherical D & Shofu & 017616 \\
Human Enamel & - & - \\
\hline
\end{tabular}
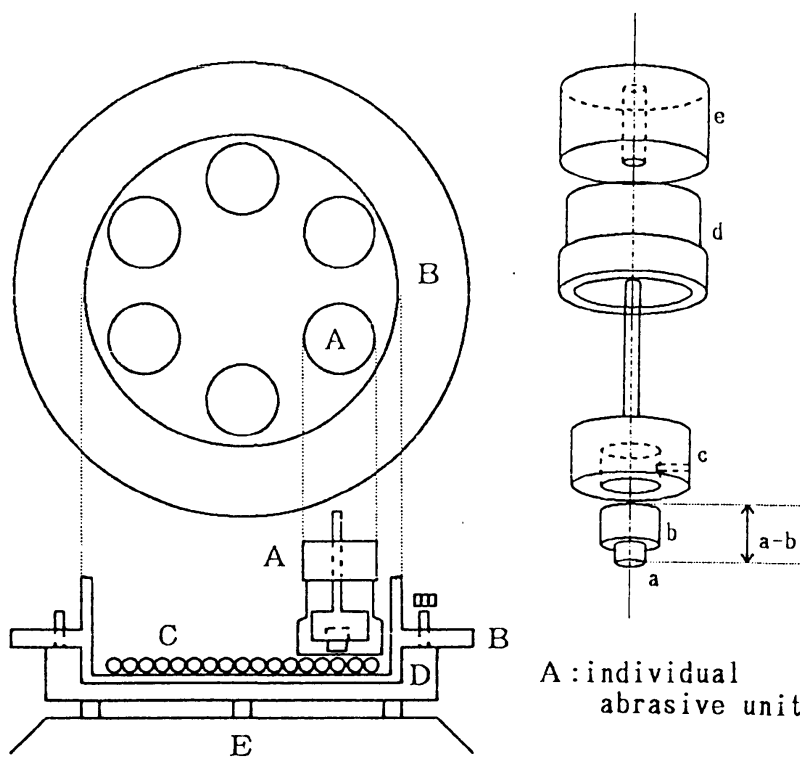

A : individual

abrasive unit

Fig. 1 Schematic diagrams of a polishing machine and an individual abrasive unit. The motor (E) delivers a vibratory force vertically and horizontally upwards to the metal frame of machine (D) which finally transmits to the acrylic plate (B). By the force, six of the individual abrasive units (A) placed on the acrylic plate were moved around with vibration and sliding on abrasive particles $(\mathrm{C})$ together.

The individual abrasive unit (A) consists of $a$ : specimen, $\mathrm{b}$ : specimen holder, $\mathrm{c}$ : main holder, $\mathrm{d}$ : holder protector and e : load $250 \mathrm{~g}$.

for $24 \mathrm{~h}$, and finally the surface was finished with emery paper $\# 800$. Specimens of human enamel were obtained by cutting the appropriate labial coronal area $(7 \times 7 \mathrm{~mm})$ from extracted upper incision teeth. The surface of tooth enamel was finished with a \#800 emery paper to smooth the surface and make it perpendicular. Six specimens of each materials were made and stored in $37^{\circ} \mathrm{C}$ water for a minimum period of $24 \mathrm{~h}$ prior to each test.

Wear test: The wear was tested with a combination of a two-body system and an abrasive slurry, using a polishing machine (VIBRO-POLISH ML-201, Marutou KK, Japan) developed for preparing a microscopic sample. Fig. 1 shows the schematic diagram of a 
polishing machine and an individual abrasive unit for a sample holding. The sample was tightly attached to a specimen holder ( $\phi 10 \mathrm{~mm} \times 5 \mathrm{~mm}$ height) with an adhesive, in a system fixed to the main holder by a screw. The individual abrasive unit, with a $250 \mathrm{~g}$ load, was placed on the acrylic plate containing an abrasive particles. The unit (Fig. 1-A) was moved around on the abrasive particles with sliding and vibrating and the specimen was abraded. Six specimens were tested together. The amount of abrasion was expressed as a difference in the overall height of the test specimen (Fig. 1a-b) before and after $15 \mathrm{~min}$ and $30 \mathrm{~min}$ test cycles. Before every measurement, the specimens were washed in an ultrasonic bath for 10 min. The measurements were made with a standard micrometer exact to $0.01 \mathrm{~mm}$, six readings were taken for each specimen and averaged. The mean wear for each material was calculated from the wear of six specimens. Two types of abrasive slurries (\#800 and \#1500) containing green carborundum particles $(20 \mu \mathrm{m} \mathrm{SiC}$ and $10 \mu \mathrm{m} \mathrm{SiC}$ respectively) were prepared by mixing with $40 \mathrm{ml}$ water. The slurry was spread over the acrylic plate.

Knoop hardness: Six specimens of each material were prepared as described above. Knoop hardness was measured by Micro hardness meter (Akashi KK, Japan). A $50 \mathrm{~g}$ load was used for microfilled resins and $100 \mathrm{~g}$ load for the others.

Filler content: Composites were mixed according to the manufacturers' directions and left to cure for $1 \mathrm{~h}$. Six specimens of each composite were weighed and placed respectively in crucibles that were weighed in advance. They were heated in a $500^{\circ} \mathrm{C}$ oven for $5 \mathrm{~h}$ and left in a desiccator. The combined weights of the crucible and specimen were measured until the weights were stabilized. The filler content ( $w \mathrm{t} \%$ ) was calculated from the difference of weight of specimen before and after heating.

Compressive strength, Elastic modulus and Destructive energy: According to ADA specifications, six cylindrical test specimens ( $\phi 6 \mathrm{~mm} \times 12 \mathrm{~mm}$ height $)$ of each composite and an amalgam, were prepared and stored in $37^{\circ} \mathrm{C}$ water for $24 \mathrm{~h}$. The end surface were polished plane and parallel on a $\# 800$ emery paper before testing. The measurements were performed in an Instron Universal Testing Machine (Instron Co., Quinsy, Mass) with a cross-head speed of $5 \mathrm{~mm}$ per min.

The Student $t$ test was employed to calculate the statistical significance of the data.

\section{RESULTS}

Wear loss: The abrasion was expressed as the reduction in height of the specimen in microns per $15 \mathrm{~min}$ and $30 \mathrm{~min}$ (Table 2). In all materials, the wear loss increased linearly for $30 \mathrm{~min}$. Conventional resins, particularly posterior restorative resins, showed significantly higher wear rate than microfilled resins $(\mathrm{p}<0.01)$. Human enamel and Spherical $\mathrm{D}$ abraded with a GC \#1500 particles ( $10 \mu \mathrm{m} \mathrm{SiC} \mathrm{particles),} \mathrm{had} \mathrm{the} \mathrm{greatest} \mathrm{wear} \mathrm{resistance}(\mathrm{p}<0.01)$ and those abraded with a $\# 800$ emery paper ( $20 \mu \mathrm{m}$ SiC particles) had wear resistance similar to that of the microfilled resins. The effect of the size of abrasive particles on wear rate differed with the material tested (Fig. 2). The larger abrasive particle size resulted in a slightly higher wear rate for the conventional composites, although the differences were not pronounced. Spherical D and human enamel also showed the same tendencies as the conventional composites, and significant differences were observed between $10 \mu \mathrm{m} \mathrm{SiC}$ particles and $20 \mu \mathrm{m}$ 
Table 2 Wear loss $(\mu \mathrm{m})$ by the reduction in height of specimen abraded with $\# 800$ and $\# 1500$ for 15 and $30 \mathrm{~min}$

\begin{tabular}{|c|c|c|c|c|}
\hline \multirow{2}{*}{$\begin{array}{c}\text { Particle size } \\
\text { Time } \\
\text { Materials }\end{array}$} & \multicolumn{2}{|c|}{$\# 800$} & \multicolumn{2}{|c|}{$\# 1500$} \\
\hline & $15 \mathrm{~min}$ & $30 \mathrm{~min}$ & $15 \mathrm{~min}$ & $30 \mathrm{~min}$ \\
\hline$P-10$ & $286(19)$ & $535(19)$ & $280(19)$ & $506(32)$ \\
\hline Clearfil Posterior & $265(14)$ & $513(16)$ & $284(44)$ & $510(38)$ \\
\hline Clearfil F II & $230(8)$ & $488(16)$ & $258(21)$ & $476(29)$ \\
\hline Adaptic & $244(25)$ & $482(16)$ & $250(23)$ & $466(21)$ \\
\hline Silar & $185(13)$ & $322(19)$ & $217(48)$ & $407(61)$ \\
\hline Microrest AP & $176(18)$ & $312(27)$ & $229(18)$ & $435(21)$ \\
\hline Superlux & $137(23)$ & $239(27)$ & $171(28)$ & $307(31)$ \\
\hline Spherical D & $136(23)$ & $241(32)$ & $110(9)$ & $187(7)$ \\
\hline Human enamel & $156(14)$ & $301(19)$ & $' 114(20)$ & $226(32)$ \\
\hline
\end{tabular}

( ) : standard deviation $\quad n=6$.

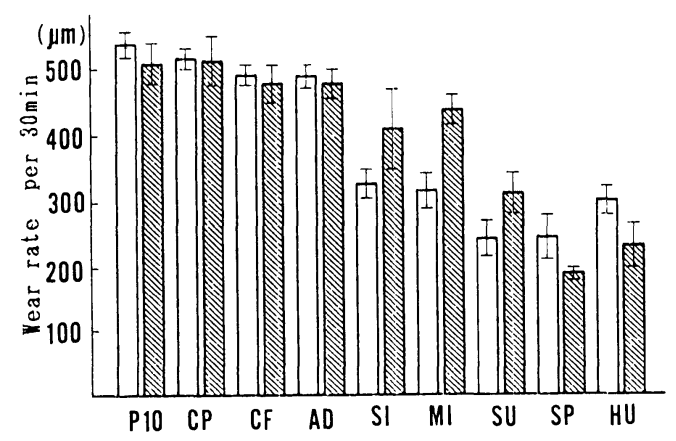

Fig. 2 The effect of the size of abrasive particles on wear rate. plain bars: abraded with $\# 800(20 \mu \mathrm{m} \mathrm{SiC})$ hatched bars: abraded with \#1500 (10 $\mu \mathrm{m} \mathrm{SiC)}$ Vertical lines indicate the range of six specimens. Materials ; P10 : P-10, CP : Clearfil Posterior, CF : Clearfil F II, AD : Adaptic, SI : Silar, MI : Microrest AP, SU : Superlux, SP: Spherical D, HU : Human Enamel

$\mathrm{SiC}$ particles $(\mathrm{p}<0.01)$. In contrast, microfilled resins abraded with larger abrasive particles had significantly lower wear rates $(\mathrm{p}<0.01)$.

Relationships between filler content, mechanical properties and wear: Table 3 shows the inorganic filler content (wt \%) and such mechanical properties as Knoop hardness, compressive strength, elastic modulus and destructive energy. Using regression analysis, the correlation coefficients between these properties and wear rates were determined (Fig. 3). The correlations were found between the wear rate for $30 \mathrm{~min}$ and inorganic filler content, Knoop hardness, elastic modulus and destructive energy. The correlation between the wear rate and compressive strength was not clarified. Figure 3 shows the scatter diagrams and the correlation coefficient. 
Table 3 Filler content and mechanical properties of materials tested

\begin{tabular}{|c|c|c|c|c|c|}
\hline Materials & $\begin{array}{l}\text { Filler } \\
\text { contnt } \\
(w t \%)\end{array}$ & $\begin{array}{l}\text { Knoop } \\
\text { hardness }\end{array}$ & $\begin{array}{c}\text { Compressive } \\
\text { strength } \\
\left(\mathrm{kgf} / \mathrm{cm}^{2}\right)\end{array}$ & $\begin{array}{c}\text { Elastic } \\
\text { modulus } \\
\left(\mathrm{kgf} / \mathrm{cm}^{2} \times 10^{4}\right)\end{array}$ & $\begin{array}{c}\text { Destructive } \\
\text { energy } \\
\left(\mathrm{cm}^{-} \mathrm{kgf} / \mathrm{cm}^{2}\right)\end{array}$ \\
\hline$P-10$ & $83.5(0.4)$ & $83.4(5.0)$ & $3188(102)$ & $14.3(0.3)$ & $185(16)$ \\
\hline Clearfil Posterior & $8 . .6(0.2)$ & $77.5(5.3)$ & $2929(214)$ & $12.6(0.6)$ & $137(67)$ \\
\hline Clearfil F II & $76.2(0.1)$ & $50.5(1.6)$ & $2150(104)$ & $11.7(0.5)$ & $200(18)$ \\
\hline Adaptic & $78.4(0.3)$ & $56.5(3.8)$ & $2243(61)$ & $13.1(0.5)$ & $166(6)$ \\
\hline Silar & $51.4(0.1)$ & $34.6(0.9)$ & $2519(88)$ & $6.9(0.4)$ & $406(21)$ \\
\hline Microrest AP & $45.5(0.2)$ & $29.2(3.2)$ & $2556(97)$ & $6.9(0.4)$ & $438(38)$ \\
\hline Superlux & $34.5(0.7)$ & $20.6(2.5)$ & $2536(281)$ & $4.1(0.3)$ & $753(106)$ \\
\hline Spherical D & & $139.3(16.9)$ & $4196(270)$ & $17.5(0.4)$ & $216(26)$ \\
\hline Human Enamel & & $341.3(48.0)$ & - & & - \\
\hline
\end{tabular}

( ) : standard deviation $n=6$
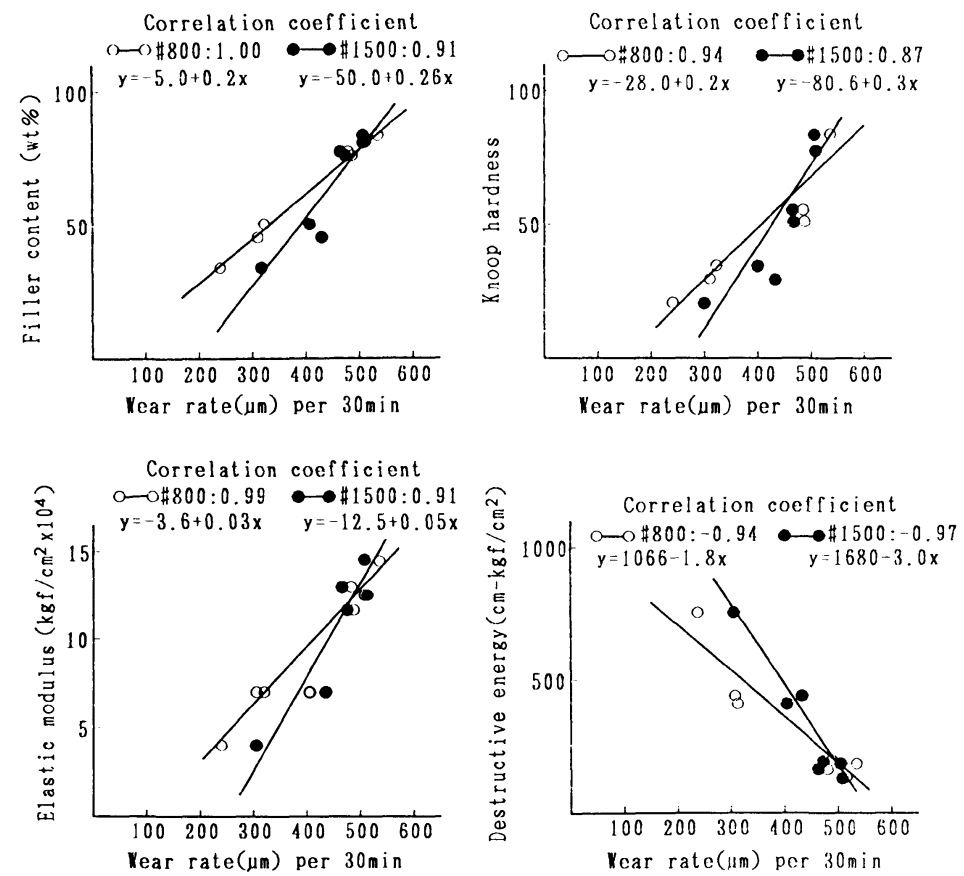

Fig. 3 Correlations between filler content, knoop hardness, elastic modulus or destructive energy and wear rates per $30 \mathrm{~min}$.

\section{DISCUSSION}

The previously reported in vitro wear tests ${ }^{1,2,6-8)}$ were the single pass, two-body system or three-body system type. In this wear test, materials were subjected to vibrating and sliding action and achieved a two-body type of contact with abrasive slurry or acrylic dish continuously. Two body systems usually reflect clinical wear ranking between the amalgam and a composite resin ${ }^{9}$. In this present study, the amalgam had a lower wear rate than composites. Conventional resins differed from the microfilled resins. The microfilled resins 
exhibited lower wear rates, indicating a higher resistance to the sliding and vibrating abrasive action. These results were in accordance with some clinical observations ${ }^{3-5)}$.

On the other hand, microfilled resins not in contact with enamel cusps of opposing dentitions showed considerably lower wear rates but those in contact with the cusps were damaged and generated microcracks ${ }^{10)}$. The present test consists of vibrating cylindrical specimen in a specimen holder moved around on abrasive slurry with sliding. The intensity of vibrating action would not be enough to generate microcracks or decrease the height of the specimen but be enough to lead fatigues of materials. The fatigue would cause the lack of the bond between the matrix and the filler particles. And also one of the factor of wearing would have resulted from insufficient matrix to bond filler particles together. Accordingly, the better wear resistance demonstrated by the microfilled resins must be related to the lower filler content, that is, less bonding phase between filler and matrix, and the smaller size of filler, because on large fillers higher stress might be concentrated than on microfillers.

Li, Y. et. al. ${ }^{11)}$ examined the wear of the resins produced by hydroxyapatite sliders. The resins were prepared with several levels of filler content increase and there was a slight trend for reduced wear resistance with increased filler size. Using regression analysis, the positive correlation was detected between filler content and wear rate (Fig. 3). Composites employed in this study contained different types of filler and matrix, but the wear behavior was consistently influenced by filler content. For the relationship between abrasion of conventional composites and filler particles, Jørgensen ${ }^{12)}$ reported that the filler particles on the one hand protect the matrix against abrasion, but cause, on the other hand, with time an increase of the surface roughness of the composite and thereby via increased friction an increase of the abrasion.

Composites containing a higher filler content showed relatively higher knoop hardness and elastic modulus, and lower destructive energy. Undoubtedly the mechanical properties of the filler and also matrix seemed to play an important role.

The influence of the size of the abrasive particle is not clear, but the microfilled resins, conventional composite and others had different wear resistance. With the smaller size (10 $\mu \mathrm{m}$ ) of the abrasive particles, microfilled resins were more abraded, although the amalgam and human enamel were less abraded, and conventionals showed no significant change in wear rate between $10 \mu \mathrm{m} \mathrm{SiC}$ and $20 \mu \mathrm{m} \mathrm{SiC}$. Conventional composites contain approximately $70-80 \%$ by weight of inorganic filler, which range in size from 1 to $100 \mu \mathrm{m}, 20 \mu \mathrm{m}$ on average $^{13)}$. The two sizes of abrasive particles are within the range of the filler size. Therefore the difference in wear rate should not be pronounced ${ }^{14)}$. It is also likely that these parameters play different roles depending on the type of material subjected to wear.

\section{CONCLUSION}

The wear of composite resins polished by machine for preparing a microscopic sample was tested. An amalgam and human enamel were tested as controls. The wear test consists of vibrating cylindrical specimens in a specimen holder loaded $250 \mathrm{~g}$, moved with sliding on an abrasive slurry. $10 \mu \mathrm{m} \mathrm{SiC} \mathrm{and} 20 \mu \mathrm{m} \mathrm{SiC} \mathrm{abrasive} \mathrm{particles} \mathrm{were} \mathrm{compared.} \mathrm{Mechanical}$ properties of composite resins were also studied and evaluated in relation to the wear. 
Conventional composites showed much higher wear than the microfilled resins. The amalgam and human enamel abraded with $10 \mu \mathrm{m}$ SiC particles, had the greatest wear resistance, and those abraded with $20 \mu \mathrm{m} \mathrm{SiC}$ particles had wear resistance similar to that of the microfilled resins. The effect of the size of abrasive particles on wear differed with the material tested. Filler content, Knoop hardness, elastic modulus and destructive energy were well correlated with wear rate.

\section{REFERENCES}

1) McCabe, J. F. and Smith, B. H. : A method for measuring the wear of restorative materials in vitro, $B r$ Dent J 151 (10) : 335-338, 1981.

2) Fan, P. L., Powers, J. M. and Craig, R. G. : In vitro wear of microfilled and visible light-cured composites, J Dent Res 58 (11) : 2116-2119, 1979.

3) Phillips, R. W. , Avery, D. R., Mehra, R., Swarz, M. L. and McCune, R. J. : Observations on a composite resin for class II restorations: Three-year report, $J$ Prosth Dent 30 (6) : 891-897, 1973.

4) Leinfelder, K. F., Sluder, T. B., Sockwell, C. L., Strickland, W. D. and Wall, J. T. : Clinical evaluation of composite resins as anterior and posterior restorative materials, $J$ Prosth Dent 33 (4) : 407-416, 1975.

5) Van, G. G. and Gronas, D. G. : In vivo evaluation of the wear of restorative resin, J Am Dent Assoc 104 (33) : 333-337, 1982.

6) McKinney, J. E. and WU, W. : Relationship between subsurface damage and wear of dental restorative composites, J Dent Res 61 (9) : 1083-1088, 1982.

7) Powers, J. M., Ryan, M. D., Hosking, D. J. and Goldberg, A. J. : Comparison of in vitro and in vivo wear of composites, J Dent Res 62 (10): 1089-1091, 1983.

8) Joseph, K., Roy, E. K. and Don, M. : The relationship of weight loss to surface roughness of composite resins from simulated toothbrushing, J Prosth Dent 47 (5) : 505-513, 1982.

9) Tani, Y., Suzuki, K. and Yuasa, S.: A new method for measuring the wear of composite restorative materials, Dent Mater J 2 (1) : 124-133, 1983.

10) Horie, K. : Studies on the occlusal wear of posterior composite resin restorations, Part 2. Clinical evaluation, Koubyoshi 51 (1) : 45-65, 1984. (in Japanese)

11) Li, Y., Swartz, M. L., Phillips, R. W., Moore, B. K. and Roberts, T. A. : Effect of filler content and size on properties of composites, J Dent Res 64: 1396-1401, 1985.

12) Jørgensen, K. D. : Restorative resins : abrasion vs. mechanical properties, Scand J Dent Res 88 : 557 $568,1980$.

13) Phillips, R. W. : Skinner's Science of Dental Materials, 8th ed., W. B. Saunders Co. 1982, pp. 226.

14) Harrison, A. and Moores, G. E. : Influence of abrasive particle size and contact stress on the wear rate of dental restorative materials, Dent Mater 1 (1) : 15-18, 1985. 
の実験を行なった。術後 8 週間, EVA-MMA, KP-MMA，HAP は何んらの炎症反応もみられなかっ た。ラットにおいて, EVA-MMA，KP-MMA は 4 週間 後では対照の PMMA と同程度の反応を示すようになっ た。in vivo と in vitro の研究から EVA コンポジットは 根充剤として最適であり, $\mathrm{HPA}$ と $\mathrm{ZrO}_{2}$ の添加は生体適 合性とX線造影性を向上させた。

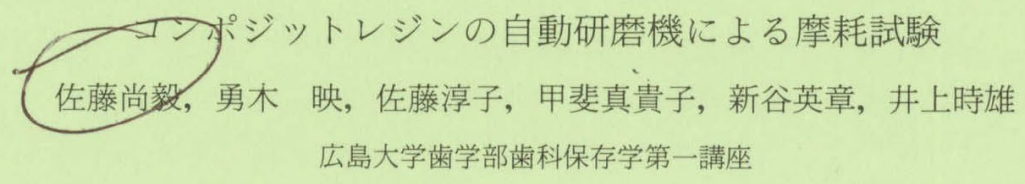

顕微鏡試料作製用自動研磨機を用い， 7 種のコンポ ジットレジンについて, 研磨材 $\mathrm{GC} \# 800(20 \mu \mathrm{m} \mathrm{SiC})$, GC \# $1500(10 \mu \mathrm{m} \mathrm{SiC})$ にる摩耗試験を行い, Human Enamel, Amalgam を対象として用いた。この自動研磨 機は振動と擦り合わせを同時に行うことが可能である。 さらに,コンポジットレジンの機械的性質を調へ摩耗 に影響を与える因子について検索を行った。

従来型レジン (P-10, Clearfil Posterior, Clearfil F II,
Adaptic) は MFR (Silar, Micro rest AP, Superlux) より摩耗量が多かったが, 研磨粒子が小さい\# 1500 では その差が少なくなった。Human Enamel, Amalgam は \# 800 では MFR と同程度の摩耗量を示し,\# 1500 では最 も耐摩耗性を示した。

レジン摩耗量と圧縮強度間には相関は認めなかった が, レジン摩耗量と硬度, フィラー含有量, 弾性率, 破 壊エネルギーとの間に相関が認められた。 